\title{
God and war in context of Carl Schmitt's political thinking
}

\section{Petr SLOVÁČEK}

\author{
Ústav středoevropských studií, Fakulta veřejných politik, Slezská Univerzita v Opavě \\ Institute of Central-European Studies, Faculty of Public Policies, Silesian University in Opava \\ Hradecká 665/17, 74601 Opava, Czech Republic \\ petr.slovacek@fvp.slu.cz
}

\section{Introduction}

War is an inherent phenomenon of human history we can think of as something remote only in our contemporary life context. But it is not a commonplace; the opportunity of such a remote view results only from European response to the dreadful experience of World War II. Thus, considering certain abnormality of our position, war finds legitimate thematization in political philosophy as an adverse and simultaneously still present part of history. If we want to confront an authentic, influential and ever relevant approach to the phenomenon, we cannot bypass political thinking of Carl Schmitt (1888-1985) that made not only theoretical and diagnostic base of the possibility of war and of the reality of violence, but at the same time, its foundations were formulated on the background of the experience and consequences of World War I in Germany. ${ }^{1}$ C. Schmitt was born in Plettenberg (Northern Rheinland-Westfalen) as son of a Catholic clerk. In 1914, he was 26 years old; thus when he was 30 , he had to cope with radical change of circumstances - the unprecedented economic growth of Wilhelmian Germany was followed by war and after that by dismal situation of chronically politically unstable Weimar Republic. ${ }^{2}$ Due to the systematic emphasis put

1 Compare Leo STRAUSS, Notes on Carl Schmitt "The Concept of the Political", in: Heinrich MEIER, Carl Schmidt and Leo Strauss. The Hidden Dialogue, Chicago 1995, 97: "Enemy" therefore takes precedence over "friend", because "the potential for a fight that exists in the region of the real" belongs "to the concept of the enemy" - and not already to the concept of the friend as such, and "man's life" gains "its specifically 'political' tension" from the potential for war, from the "dire emergency", from the most extreme possibility." But the possibility of war does not merely constitute the political as such; war is not merely within an "autonomous" region - the region of the political - but for man simply, because war has and retains a "relationship to the real possibility of physical killing." A lot of interpreters of western political thinking see factors inspiring deep changes of political thinking in the experience of serious social crises, civil wars and violent conflicts. In this regard, we can put side by side Thucydides, Plato, Machiavelli, Hobbes and Schmitt. For example E. Voegelin tends to such opinion: "In an hour of crisis, when the order of a society flounders and desintegrates, the fundamental problems of political existence in history are more apt to come into view than in periods of comparative stability." See Eric VOEGELIN, The New Science of Politics: An Introduction, Chicago 1974, 1-2.

2 C. Schmitt was not advocate of monarchism and surely not of its Wilhelmian form. If new Berlin of early $20^{\text {th }}$ Century can be considered a symbol of such form of monarchism, the Catholic C. Schmitt felt like a stranger there. But while trying to understand his position, we should not forget that the German Empire of 1871-1914 underwent huge and multilateral development. C. Schmitt was maturing in that context - at the time of outbreak of World War I he was 26 years old - and, principally, acquiring his classical and legal education. C. Schmitt became famous particularly in the time of the Weimar Republic, but his socialization does not fall within that period of the German history. For more details on the situation of the German Empire in the years from its establishment to outbreak of World War I see Ulrich HERBERT, Geschichte Deutschlands im 20. Jahrhundert, München 2014, 34-67. 
on violence and war, Schmitt's thinking constitutes an antipole to better known position of $\mathrm{H}$. Arendt who placed violence outside the space of rational analysis. ${ }^{3}$ Unlike $\mathrm{H}$. Arendt who claims that "violence itself is incapable of speech (...) Because of this speechlessness political theory has little to say about the phenomenon of violence and must leave the discussion to the technicians $(\ldots)^{\prime \prime}{ }^{4}$, to $\mathrm{C}$. Schmitt, violence and thus also war remains a point of reference of all political thinking:

"The specific political distinction to which political actions and motives can be reduced is that between friend and enemy. [...] The distinction of friend and enemy denotes the utmost degree of intensity of a union or separation, of an association or dissociation." 5

His position is important also to our topic of relation of God and war, for two reasons: a) biographical and b) systematic. In the first case, C. Schmitt was a Catholic thinker who understood his faith as an integral part of mental life. ${ }^{6}$ In the second case, C. Schmitt's name is connected with political theology, with the effort to extricate man from the Hobbesian loneliness and self-centredness of modern age that does not count with a personal God in political space, leaving it completely to private sphere. For the two above stated reasons, C. Schmitt cannot be abstracted from his religious belief.

Thus it is completely justified to seek the bond between God and war in C. Schmitt's thinking. The relation can be even approached as relation between two basic poles of Schmitt's work. The possibility of violence and war stands in its centre; the authentic relation to God determines the provenance of his existence and self-understanding. The following pages will be aimed at determining the character of the above stated relation in the space of his political theology that, to him, was both a process in the history of political thinking and an actual project understood as alternative to political philosophy. These two aspects of Schmitt's thoughts correspond with his analytical and critical approach to the development of modern thinking.

Nevertheless, by choosing this figure, we get into a quite difficult position that, in C. Schmitt's case, must be re-emphasized. The thing is that C. Schmitt is both an enigmatic and controversial figure in the history of political thinking of the $20^{\text {th }}$ century. His NSDAP membership in 1933-1936 is a painful fact that is not restricted only to passive participation and conformist adaptation. Apart from the legal and ideological support to the regime in the texts from the period of 1933-1936, Schmitt's reputation was discredited the most

3 As N. Bobbio states, political thinking is constituted by two basic antitheses: oppression-liberty; unity-order. In political thinking of modern age, the first of them was developed by J. Locke, and the second, by T. Hobbes. If restricting ourselves to political philosophy of the $20^{\text {th }}$ Century, we can see the same relation between $\mathrm{H}$. Arendt and C. Schmitt. In this sense, their positions are complementary and contradictory. Compare Norberto BOBBIO, Thomas Hobbes and the Natural Law Tradition, Chicago 1993, 29.

4 Hannah ARENDT, On Revolution, Harmondsworth 1963, 19.

5 Carl SCHMITT, The Concept of the Political, London 2007, 19.

6 Helmut QUARITSCH, Positionen und Begriffe Carl Schmitts, Berlin 2010, 12-13: "Dem politischen Denker Schmitt hingegen fehlten die normativen Haltergriffe, an ihre Stelle traten die drei Grundprägungen seines Daseins - er war Katholik, er war Etatist, und er war Nationalist. (...) Seine Katholizität war radical, das geistige Bild seiner Konfession war damals aber auch bunter als heute." 
by his anti-Semitic engagement which, however, as J. W. Bendersky states, was not really trusted even by Schmitt's enemies (principally by Alfred Rosenberg ${ }^{7}$ ) from "Das Schwartze Korps" circle, predicting Schmitt's future in the alternatives of emigration or concentration camp ${ }^{8}$ as well as public support to political violence of the Night of the Long Knives from 29 to 30 June 1934, that can be found in the article called "Der Führer schütz das Recht". 9 But the certainty ends at that point and the basic questions begin to which researchers cannot find a univocal answer. Was C. Schmitt an authentic political philosopher (or political theologist), or only an opportunistic intellectual? ${ }^{10}$ What was his role in the period of crisis and particularly in the last months of the Weimar Republic when he acted as representative

7 Alfred Rosenberg, NSDAP party ideologist, is author of so called "Mitteilungen zur weltanschaulichen Lage" from 8 January 1937, in which he characterizes Schmitt's position as incompatible with NS ideology, due to low importance of the people (Volk). The "Mitteilungen" are very informative for assessment of C. Schmitt's position towards NS ideology: "Dieser neutrale Begriff der Politik aber, und das ist das Erstaunlichste, wird zum Herren gemacht über die tragenden Werte der nationalsozialistichen Weltanschauung, in erster Linie über den Begriff des Volkes. Dieser Kern unserer Weltanschaung wird herabwürdigt zur Sphäre der Selbstverwaltung. Das Volk ist ein bescheidener Teil des Feldes, auf dem die Theologischen Gegensätze ausgetragen werden. Das ist der Kern der Lehre Carl Schmitts." In 1939, C. Schmitt is attacked again, that time in "Dienststelle für Schrifttumspflege": "C. Schmitt hat, nachdem er einmal Bewunderer des geschlossenen katholischen System geworden ist, die Zwangjacke der Katholizität nicht auszuziehen vermocht. Selbst in seiner fast offiziösen Schrift 'Staat, Bewegung, Volk' finden sich die eigentümliche Linien dieser denkweise."

8 C. Schmitt was NSDAP member from May 1933, joining NSDAP after M. Heidegger who had invited him to join by a letter. C. Schmitt has another thing common with M. Heidegger - he never made appologies for his membership. Schmitt's anti-Semitism is also a fact that is interpreted in different ways, as: a) theological; b) opportunist; c) not racially motivated; d) defensive; c) standard equipment of German intellectual of the second half of the $19^{\text {th }}$ century and of the beginning of the $20^{\text {th }}$ Century. For objective assessment of Schmitt's anti-Semitism see Joseph W. BENDERSKY, Carl Schmitt at Nuremberg, in: Telos, 20, 1987, 72, 96: "Confronted with the possibility of his arrest, he become more outspoken in advocating anti-Semitism, defending the Nuremberg laws and organizing a conference on the question of purging Jewish influence from German law. This was self-serving, dishonest, and morally despicable - and it failed to convince even his opponents that it was anything but a sham." In the issue of science of difference of races, he had published his opinion in 1916 already. See Carl SCHMITT, Theodor Däublers "Nordlicht" - Drei Studien über die Elemente, den Geist und die Aktualität des Werkes, München 1916, 14: "Die ganze Romantik der Rassenlehren beruht an ähnlichen, namentlich morphologischen Spekulationen, und Leute, die sich Realpolitiker zu nennen lieben, machen naturwissenschaftliche, angeblich exakte Rassenunterschiede geltend, während sie im Grunde nur moralische Deutungen meinen. Selbst der Gegensatz von Kreis und Ellipse ist noch nicht vergessen; er hat in der Vergleichung von Lang- und Rundschädeln, Dolicho- und Brachycephalen, eine noch ziemlich intensive Fortexistenz."

9 Carl SCHMITT, Der Führer schützt das Recht. Zur Rechtstagsrede Adolf Hitlers vom 13. Juli 1934, in: Deutschen Juristen-Zeitung, 15, 1934, 39, 945-950. But the text must be understood in the context of the events of that time, because the approximately 200 victims of the Night of the Long Knives included also Kurt von Schleicher, to whose circle C. Schmitt belonged; on the other hand, also the text justifying violence criticizes unlimited violence based on the wish to settle personal accounts, which should be followed by "besonders strenge Strafverfolgung" to the originator. For more details see QUARITSCH, 88.

10 The first scientific biography was written in 1983 by Joseph W. Bendersky and its name is "Carl Schmitt: Theorist for the Reich". Later interpreters trying to offer a synthetic picture of Schmitt's thinking include Gopal Balakrishnan and Heinrich Meier. But G. Balakrishnan's and H. Meier's interpretations are diametrically opposed, which has significance from the perspective of meaningfulness of our text. G. Balakrishnan believes that Schmitt's thinking is not led by any immanent principles that provide for his identity in time; moreover, he considers Schmitt eclectic and opportunist thinker. On the contrary H. Meier tries to show that the core of Schmitt's thinking consists in the belief of the need of political theology, putting it in the centre of Schmitt's work. H. Quaristsch holds similar position. For more detail see: Joseph W. BENDERSKY, Carl Schmitt: Theorist for the Reich. Princeton 1983; Gopal BALAKRISHNAN, The Enemy: An Intellectual Portrait of Carl Schmitt. London 2000; Heinrich MEIER, The Lesson of Carl Schmitt: Four Chapters on the Distinction between Political Theology and Political Philosophy, Chicago 1998. 
of von Papen's government in the lawsuit of the Empire vs. Prussia? ${ }^{11}$ Is Schmitt's NSDAP engagement mere adaptation, or can we find moments supporting the Nazi ideology in his texts written before 1933, as R. Kempner, a Nuremberg investigator tried to show in $1947 ?^{12}$ What character has Schmitt's anti-Semitism, when considering not only the documents from the period after 1933, but primarily his Jew friends from prewar years? And last but not least, what was Schmitt's real role in postwar intellectual period; was his withdrawal to safe silence only a strategic step? ${ }^{13}$

These are only some of the fundamental questions that researchers ask and to which they give completely different answers, often supported by identical texts. In this regard, C. Schmitt is an entirely ambiguous figure of political thinking during the $20^{\text {th }}$ century. But circumspect judgements are suited, particularly if our reflections cover broader context of Schmitt's live and, necessarily, also the always politically relevant and complicated character of his work situated in the space delimited by legal science, literary criticism, political analyses, philosophy and certainly last but not least also by theology. ${ }^{14}$

11 The lawsuit was provoked by Hindenburg's decree from 20 July 1932, by which Reichs-chancellor Franz von Papen was authorized by the inglorious paragraph 48 of Weimar Constitution to take control over Prussia, which is considered an important step in the process of Nazis' rising to power. C. Schmitt acted in the lawsuit as representative of the Reichs-government, and one of his arguments relied on the statement that the Prussian parliament with dominant SPD, when trying to forbid NSDAP, exceeded its authority and appropriated, without authorization, the right to decide about who is friend and who is enemy, which is reserved only to independent government. So, from this perspective, C. Schmitt supported the forces aimed at liquidation of the Weimar Republic. Nevertheless, even that role of his seems problematic. Perhaps C. Schmitt only performed his role of lawyer? Schmitt's notes from that period, published after his death, evidence his dismal mental condition testifying inner disapprobation of the events of that time. C. Schmitt says in them verbatim that he considers that conflict personally humiliating and his situation extremely dismal. For analysis of legal and legal-philosophical positions competing in the conflict see David DYZENHAUS, Legal Theory in the Collapse of Weimar: Contemporary Lesson?, in: American Political Science Review, 91, 1997, 1, 121-134. For more detail on the important relation between the (philosophical-) legal theory and practice in German cultural context see Arthur. J. JACOBSON - Bernhard SCHLINK, Weimar. A Jurisprudence in Crisis, Berkeley 2000, 1-39.

12 C. Schmitt's assessment in this aspect is particularly difficult. It is unquestionable that Schmitt's texts from the period of 1933-1936 show effort to adapt to the national-socialist spirit. Nevertheless, it is very probable that national-socialist ideologists did not believe his effort.

13 For analysis of Schmitt's postwar actions and for assessment of his flight to "safe silence" see Dirk van LAAK, Gespräche in der Sicherheit des Schweigens. Carl Schmitt in der politischen Geistesgeschichte der frühen Bundesrepublik. 2. Auf., Berlin 2002.

14 C. Schmitt evaluates his role of the period of 1933-1936 (1945) at many places and from different angles. Very informative is the recorded conversation with investigator Robert Kempner from 3 April 1947 that took place within his investigation in Nuremberg. C. Schmitt stated in it unambiguously the fact that also later research of totalitarian regimes confirms, their unprecedented character, and acknowledged at the same time also the failure of intellectual elites who were not able to identify that danger. That failure concerns C. Schmitt even more as he, as political philosopher and scientist, dealt with the phenomenon of dictatorships, of which R. Kempner naturally reminded him: "Kempner: You were not familiar with any dictatorship? Schmitt: No. This total dictatorship was actually something new. Hitler's method was new. There was only one parallel, Lenin's Bolshevik dictatorship." The translation of the conversation was published in Joseph W. BENDERSKY, Interrogation of Carl Schmitt by Robert Kempner. in: Telos, 20, 1987, 72, 107. For branch and thematic variedness of Schmitt's work compare QUARITSCH, 12: "Seine Schriften zum Verfassunsrecht der Weimarer Republik blieben Arbeiten eines Juristen, der sich zwar einfallsreich und artistisch behende im Gerüst der Normen bewegte, aber von ihm gehalten wurde und in ihm verblieb; die Gedenkkontrole war jederzeit möglich. Das gilt entsprechend für seine geistes- und sozialwissenschaftlichen Arbeiten. Dem politischen Denker Schmitt hingegen fehlten die normative Haltegriffe, an ihre Stelle traten die drei materialen Grundprägungen seines Dasein - er war Katholik, er war Etatist, und er war Nationalist." 
However, in view of that ambiguity, the elaboration of our topic gets into some troubles that can be solved only by taking a specific stand. The answer to the first question decides already about the meaningfulness of reflections about C. Schmitt in the aspect of the relation of God and war. If C. Schmitt, as G. Balakrishnan states, was only an opportunist and eclectic thinker, C. Schmitt's legacy will have only historical value consisting in the possibility of analyzing the role of an intellectual in conditions of complete lack of freedom and permanent danger. On the contrary, if we agree with $\mathrm{H}$. Meier who sees the core of Schmitt's work in political theology, we get the possibility to characterize the relation of God and war and can put it, at the same time, into a broader political-philosophical context. ${ }^{15}$

The following text will be based on the assumption of identity and coherence of Schmitt's thinking in Meier's sense. At the same time, we tend to the opinion that C. Schmitt attracts interest of political philosophers rightfully, as his theory of the political acquires actual character in the modern world of religiously motivated terror, asymmetric wars and unforgettable nationalism. At the same time, C. Schmitt constitutes an alternative source to the liberal political thinking of Rawls' and Habermas' type, dominant at present and blamed by contemporary critics, actually just as by C. Schmitt, principally for rational formalism and also for omitting the physical determinateness of man. ${ }^{16}$

Nevertheless, in view of his compromising connection to Nazism, at least the following motives must be mentioned: a) relation between the philosopher and politics or individuals at power positions is a classical topic of political philosophy together with consequences on their actual philosophy. L. Strauss believes that political philosophy, due to its fundamental non-neutrality, materializes in "pure" form only in exceptional historical moments and is often governed by the principle: "non possumus scribere in eum, qui potest proscribere". This applies even more in case of a thinker who does not formulate his theory 'sub specie aeternitatis' but from the perspective of his specific, i.e. also physical, determinateness:

"First, all political concepts, images, and terms have a polemical meaning. They are focused on a specific conflict and are bound to a concrete situation; the result (which manifests itself in war or revolution) is a friend-enemy grouping, and they turn into empty and ghostlike abstractions when this situation disappears. Words such as

$15 \mathrm{H}$. Meier tries to show two points: a) C. Schmitt formulates political theology as alternative to political philosophy; b) the fundamental Schmitt's text "The Concept of the Political" was adapted in "hidden" dialogue with Jewish thinker L. Strauss, in hidden dialogue with a representative of political philosophy. In the preface to older book "Carl Schmitt and Leo Strauss. The Hidden Dialogue", H. Meier writes: "Political theology is a concept that makes distinction insofar as the determination of its intrinsic concern distinguishes political theology from political philosophy. The two are not distinct in the way that two scholarly disciplines or two relatively independent domains of human thought and action can be distinguished from each other. Rather, they are divided by their insuperably opposed answers to the question, How am I to live? (...) Carl Schmitt cannot be adequately grasped if one does not grasp the centre and the context of the work as political theology." Heinrich MEIER, Carl Schmitt and Leo Strauss. The Hidden Dialogue, Chicago and London 2005, xvi, xviii.

16 The best known include for example Ch. Mouffe who believes that modern liberal (rationalist) political thinking dangerously loses sight of the facticity of violence in the history. Compare Chantal MOUFFE, The Return of the Political, New York 1993, 2: "Schmitt's critique of liberal democracy constitutes, in my view, a challenge that we cannot ignore. Yet I also think that, by revealing the deficiencies of liberalism, he can help us - unwittingly - to identify the issues that need to be addressed and thereby to gain a better understanding of the nature of modern democracy. My objective is to think with Schmitt, against Schmitt, and to use his insights in order to strengthen liberal democracy against his critiques." 
state, republic, society, as well as sovereignty, constitutional state, absolutism, dictatorship, economic planning, neutral or total state, and so on, are incomprehensible if one does not know exactly who is to be affected, combated, refuted, or negated

by such term." 17

Czesław Miłosz, when analyzing the intellectual's position in unfree totalitarian world, documents that belief competently on examples of Polish writers whose engagement was no less surprising $i^{18}$ b) the belief of political philosophers of their superiority over their political counterparts can be easily found at Plato's already. C. Schmitt felt to be intellectually so distant from and superior over Hitler that when speaking with investigator Kempner, he suggested that talking about him was a waste of time. ${ }^{19}$

Thus in the following text, we will try to find link between war and God. We believe, and will try to show it, that war (violence) constitutes to $C$. Schmitt the horizon of authentic decision that is possible only in the space between the political thinking and God.

\section{Framework of Schmitt's thinking}

In his classical Work, "The Concept of the Political", C. Schmitt writes that the political is determinable based on the possibility of distinction of friend and enemy:

"The specific political distinction to which political action and motives can be reduced is that between friend and enemy. This provides a definition in the sense of a criterion and not as an exhaustive definition or one indicative of substantial content." 20

In "Political Theology" (1922) is sovereign that "who decides on the exception". ${ }^{21}$ Sovereign is that who determines who is friend and who is enemy. At the same time, such decision cannot be preceded by any predetermined norm as a general norm can never grasp and predict exception in its concreteness. In the text "Über die drei Arten des Rechtswissenschaftlichen Denkens" from Schmitt's problematic period, we can read the following words:

17 SCHMITT, 2007, 31.

18 Czesław MlŁOSZ, The Captive Mind, New York 1955.

19 BENDERSKY, Interrogation, 1987, 106: "Schmitt: Yes. I was from 1935 to 1936 head of the professional organization [Academy of German Law or National Socialist League of German Jurist]. U felt superior at that time. I wanted to give the term my own meaning. ... I felt superior. Kempner: You felt superior to Adolf Hitler? Schmitt: Intellectually, of course. He was to me so uninteresting that I do not want to talk about that at all." H. Quaritsch describes C. Schmitt's rather exaggerated self-evaluation with the following words: "Da er sich vor 1933 exponiert hatte, musste er wie ein Konvertit stets besondere Zuverlässigkeit und Glaubenstrene beweisen. Da grosse Chor derer, die vor 1933 die Melodie von Weimar nur mittgesummt hatten, brauchte nach 1933 nur die Notern zu wechseln. Carl Schmitt hingegen wollte nicht nur mitsingen, sondern auch ten Ton angeben." See: QUARITSCH, 106.

20 SCHMITT, 2007, 26.

21 Carl SCHMITT, Political Theology. Four Chapters on the Concept of Sovereignty, Cambridge 1985, 5: "Sovereign is he who decides on the exception." 
"It is not the command as a command, but the authority or the sovereignty of an ultimate decision given in a command, which constitutes the source of all law, that is, of all the norms and all the orders that follow from it. ... Consequently the sovereign decision can be juridically explained neither from a [i.e. antecendent] norm nor by a concrete order because for decisionism it is the decision is an absolute beginning, and the beginning (understood as apxń) is nothing else than a sovereign decision. It springs out of normative nothingness and from concrete disorder." 22

Thus the political is determined by the possibility of distinguishing friend and enemy, by the possibility of physical conflict:

"But he is, nevertheless, the other, the stranger; and it is sufficient for his nature that he is, in a specially intense way, existentially something different and alien, so that in the extreme case conflicts with him are possible. These can neither be decided by a previously determined general norm nor by the judgment of a disinterested and therefore neutral third party." 23

Nevertheless, that difference has its limit. A political conflict based on insuperable difference is understood by Schmitt as a really political conflict, when the difference is understood in political and not in moral sense, wherethrough political violence becomes goal-directed, and thus limited violence.

"The enemy is not something that for some reason we should do away with or destroy as if it had no value (...) The enemy places himself on my own level. On this ground I must engage with the opposing enemy, in order to establish the very measure of myself, my own boundaries, my own Gestalt." 24

But the political has two dimensions from which we can analyze it, wherethrough we bring the war horizon to the necessity and seriousness of the decision, both at international and at internal political level. According to Schmitt, the political is determinable by the friend/enemy distinction not only as for function but also as for its essence. In the first case, the traditional function of politics consists in identification of the enemy and in defence. In the second case, Schmitt tells us that the political as such does not exclude the possibility of realization of such level of antagonism that we could call hostility and that, in fact, signalizes state of war. The state of war, which is significant from the per-

22 Carl SCHMITT, Über die drei Arten des Rechtswissenschaftlichen Denkens, Berlin 1993, 21, 23-24. Translation into English taken from Andreas KALYVAS, From Act to the Decision: Hannah Arendt and the Question of Decisionism, in: Political Theory, 32, 2004, 3, 320-346.

23 SCHMITT, 2007, 27.

24 Carl SCHMITT, Theorie des Partisanen. Zwischenbemerkung zum Begriff des Politischen, Berlin $1975,87$. 
spective of our topic, can be either war between nations or civil war. ${ }^{25}$ Characteristics of sovereignty belong then to the player in the political field who is able to provide for safety both at internal and at international level. So for example the Weimar Republic failed in the first regard.

Such political determinateness of man cannot be reduced to other seemingly separate domains of human life, among which C. Schmitt lists aesthetics, moral, science or economy. ${ }^{26}$ So the political is not an area beside the above stated areas and it is not comparable to them. The basic difference consists in the fact that each of those areas may become medium of the political, if it causes such level of antagonism that results in physical conflict with open and real possibility of death.

"The political can derive its energy from the most varied human endeavors, from the religious, economic, moral, and other antitheses. It does not describe its own substance, but only the intensity of an association or dissociation of human beings whose motives can be religious, national (in the ethnic or cultural sense), economic, or of another kind and can effect at different times different coalition and separation." 27

The political, understood in this way is, according to C. Schmitt, an authentic dimension of human reality, wherethrough also war gets to the angle of vision of reflections about man. Nevertheless, war is wrongfully forgotten in the liberal context of thought. War becomes something unbecoming in it, as compared to competition (business), discussion (science), or possible aesthetization of life aimed at experience and self-expression (aesthetics). ${ }^{28}$ But the possibility of war that should determine the seriousness of human life and mark out the limits of life is not eliminated by such obscuring. C. Schmitt calls the modern process of obscuring the possibility of such intensification of conflict neutralization of the political, localizing its origin in T. Hobbes' work. It is caused by the fact that man forgets himself and the seriousness of his historical situatedness.

In that basic framework, three motives significant to C. Schmitt are realized; he wants to

25 Distinction of function and essence of the political is suggested by G. Slomp. G. Slomp also shows in what the specifics of Schmitt's position in context of European political thinking consists in the aspect of thematization of violence and war. According to that author, Schmitt is a completely orthodox thinker in his functional determination of the political. But he deviates from tradition the moment he puts hostility into the political as such, additionally to friendship. That differentiates him for example from T. Hobbes according to whom, politics and violence constitute exclusive concepts. On the contrary, Schmitt's position defines the political by the possibility of both opposites. See Gabriella SLOMP, Carl Schmitt and the Politics of Hostility, Violence and Terror, New York 2009, 6-10.

26 C. Schmitt published "The Concept of the Political" in three different editions in 1927 (1928), 1932, and 1933. The re-edition of "The Concept of the Political" of 1963 was based on the second edition from 1932. There are two reasons for mentioning that fact: 1) the edition from 1933 contains passages conforming to its time; 2) the edition from 1933 intensifies the difference of the domain of the political. In that sense, H. Meier believes that the text from 1933 depicts more precisely C. Schmitt's basic effort to disassociate himself from the concept of culture of modern age. Compare: MEIER, 2005, 5-6; 11-13.

27 SCHMITT, 2007, 38. Compare SLOMP, 2009, 10: "Thus political may take place in the street, in the football stadium or in the international realm, but risks to security arise like diseases: they do not only pose their threats in designated arenas. In a nutshell, Schmitt's political follows violence, hostility and terror just as form follows matter."

28 Compare Carl SCHMITT, Political Romanticism, Cambridge 1986, 18-19. 
draw attention to them by highlighting the political as an authentic human dimension determined by the possibility of distinction of friend and enemy, i.e. by the possibility of war. First, man is 'zoon politikon', man is not a pre-social and lonely being that can be found in T. Hobbes' work in both natural and social status. While this classic of modern political philosophy does not speak of the individual's obligation to lay down his life in the interest of the state (or, more generally, 'polis'), as life is the tool to preserve his life movement, Schmitt's sovereign is entitled to demand such price at the moment when the public enemy has been determined. It applies on the contrary that individual conflict aimed at killing the enemy ('inimicus') is unjustifiable to Schmitt. But man is not primarily an individual (atom) to Schmitt, thanks to speech. Speech is not mere tool but source of his dignity. In the context of our problem, it is also the vertical connecting line of man with God, a condition of their personal relation, so essential to Christian belief in tripersonal God. ${ }^{29}$ This link cannot be overestimated with regard to $\mathrm{C}$. Schmitt. He considered himself essential Christian and primarily Catholic, which also constitutes the broader context in which he conceived the issue of the political. ${ }^{30}$

Second, man is God's image and creation who was, nevertheless, affected by original sin, and is therefore ordered out to the area of relevance of political power and violence. Not unimportant is the way in which C. Schmitt presents his concept of the origin of violence. "The Concept of the Political" includes already a reference to man's original sin:

"The fundamental theological dogma of the evilness of the world and man leads, just as does the distinction of friend and enemy, to a categorization of man and makes impossible the undifferentiated optimism of a universal conception of man." ${ }^{31}$

In this regard, C. Schmitt does not constitute exception from the tradition of the European political thinking. But in the text written by him during his Nuremberg imprisonment, "Ex Captivate Salus", we can read a very nontraditional localization of biblical origin of violence, together with allusion to Heraclitus. The text is even more important to us due to the fact that it helps to deepen our understanding of the diametrical otherness of the enemy.

"The other is my brother. The Other reveals himself as my brother and the Brother, as my Enemy. Adam and Eve had two sons, Cain and Abel. Thus begins the history of mankind. This is the face of the father of all things. This is the dialectical relationship

29 Compare Carl SCHMITT, Roman Catolicism and Political Form, London 1996, 24: "(...) it is a form of human dignity which become manifest in a rational form of speech." Ibidem, Appendix, 48: "Whoever speaks is no longer alone in the world. However, it would be false to say man is alone in the world and God is not with him. Instead of the alternative, that would be a combination of both. Man is either alone or in the world. As long as he is truly alone, he is not in the world, that is, he is no longer even a man, and as long as he is a man and in this world, he is not alone."

30 C. Schmitt writes in his notes from 1948: "For me the Catholic faith is the religion of my fathers. I am Catholic not only by confession but also by historical origin, if I may say so, by race. ... This is a secret keyword to my entire mental and authorial life: the struggle for the authentically Catholic sharpening." Quoted according to Michael HOLLERICH, Carl Schmitt, in: The Blackwell Companion to Political Theology, Peter SCOTT, William T. CAVANAUGH (eds.), Oxford 2004, 110.

31 SCHMITT, 2007, 65. 
which keeps the history of the world going. And the history of the world is not over yet." ${ }^{32}$

This aspect has two consequences: i) effort to create a non-political world would be equal to effort to divinize man; ii) thus neutralization of the political is in contradiction with imperfect human nature and must be in tension with it or, at least, lead to such conditions that are in conflict with human nature. C. Schmitt takes a peculiar position here, within Christian political thinking. On one hand, he understands the political as domain of power that finds its base primarily in the physical determinateness of man, which is a motive found in Augustin's work already. But on the other hand, Schmitt does not consider the political a necessary evil, and unlike Augustin and much later acting Luther ${ }^{33}$, he does not waive the political. Schmitt reveals his understanding of the relation of theology and politics very strongly in "Political Theology 2" where he brings the issue of political relevance of theology up to date comparing the legacy of Saint Augustine and Eusebius of Caesarea, admitting legitimacy to Eusebius' political engagement. ${ }^{34}$

And finally, every moment of human history is completely unique. Man's historical character obliges man to lead a life that is not only entertaining, although even such life may surely be interesting. ${ }^{35}$ That emphasis, put by C. Schmitt on non-repeatability of events, also delimits place to the significance of decision.

We will try to complete these motives in the following text in order to show Schmitt's position with regard to the relation of God and war, mediated by specific situatedness of man, in its plasticity. It also means that the theological aspect of Schmitt's thinking will be, to certain degree, the starting point and not a problematic point.

\section{Political theology as project and process}

C. Schmitt includes the issue of the character of cognition, its sources and limits among absolutely fundamental issues. For the purposes of our article, we can divide it into two parts, the first of which will refer to the relation between cognition (philosophy) and faith

32 Carl SCHMITT, Ex Captivitate Salus, Berlin 2002, 89-90.

$33 \mathrm{C}$. Schmitt's relation to Protestantism is very complex. For us, the fact is important here that M. Luther is quite pessimistic in basic relation to politics, which results from his very negative understanding of the possibility of man's choice. On the contrary, decision is constructive for Schmitt not only at political level, but also at individual level where it constitutes human dignity that contradicts any reductionism. If L. Strauss' interpretation of Schmitt's criticism of modern concepts of civilization and culture is right, we can put Luther on an equal footing with T. Hobbes. Catholicism resists such segmentation, as we will see in more detail below. Compare SCHMITT, Roman Catholicism, 1996, 17-18. For Luther's relation to possibilities of political philosophy and his understanding of human choice see Quentin SKINNER, The Foundation of Modern Political Thought: Age of Reformation, Cambridge 2004, 3-19.

34 Carl SCHMITT, Political Theology 2. The Myth of the Closure of any Political Theology, Cambridge 1970, 66. For Eusebius of Caesarea and his political theology compare Hubertus R. DROBNER, Patrologie: Úvod do studia starokřestanské literatury, Praha 2011, 300-302.

35 Compare SCHMITT, 1970, 86: "The entire Christian aeon is not a long march but a single long waiting, a long interim between two simultaneities, between the appearance of the Lord in the time of the Roman Caesar Augustus and the Lord's return at the end of time. Within this long interim, there emerge continually numerous new worldly interims, larger or smaller, which are literally between times." 
(theology) and the second will focus on the actual dynamism or transformations of cognition in the aspect of its relation to reality. In the first case, we will discuss political theology as project, in the second case, we will discuss political theology as process. Both of these dimensions of Schmitt's understanding of sources and possibilities of cognition determine notably the thinking on the political, assigning also proper context to understanding of war. The thing is that C. Schmitt's distinction of friend/enemy cannot be reduced to political realism, although the emphasis put by him on the enemy and thus on violence, particularly in "The Concept of the Political", seems to suggest the contrary. ${ }^{36}$

\subsection{Political theology as project}

If the three above stated motives capture, from the perspective of the topic of this article, the basic limits of reflection about man, God and war, they make us face the following essential question: What is the relation between religion (theology) and philosophy in C. Schmitt's thinking? We can find the answer in his belief of the possibility and necessity of political theology. C. Schmitt belongs to a large group of thinkers of the $20^{\text {th }}$ century who saw considerable danger in modern thinking and particularly in its outcome. The Frankfurt school as crisis product of modern age diagnosed instrumentalization of reason that became mere Hobbesian calculation. Similarly, J. Habermas considers the system of power and economy an instrumentalization of public space needed for functioning of modern society, but regulated by the mechanics of its rules and laws that cannot be corrected by discourse and, therefore, defy legitimization processes. C. Schmitt understood quite similarly the basic problem of modern political philosophy and society at two levels.

At the first level, the political philosophy of modern age lost the ability to interpret the experience of late-modern society. On the other level, the political philosophy of modern age relieved the issue of legitimacy of the bond to tradition and of deeper roots, but was not able to substitute them. It replaced God only by finally dangerous substituents like for example humankind, peace, justice and progress, in Schmitt's opinion only seemingly rational goals that can lead to the demand of the last unlimited and thus total war due to the fact that they set somebody absolutely different against man. A clear and uncompromising possibility of distinction replaces biblical ambiguity with regard to human character. That caused obscuring of the reality of the political that is materialized through a dehumanizing

36 In the German preface to "The Concept of the Political" from 1963, C. Schmitt states that his preliminary concept of the political has become mere slogan and phrase, so called friend/enemy theory. 
and essentially individual moral judgment. ${ }^{37} \mathrm{C}$. Schmitt opposes it by his criterion of determination of the political that seems very militant, but its consequences lead to prevent the possibility of total war:

"Es gibt keinen rationalen Zweck, keine noch so richtige Norm, kein noch so ideales Programm, keine Legitimität oder Legalität, die es rechtvertigen könnte, dass Menschen sich gegenseitig dafür töten. ... Auch mit ethischen und juristischen Normen kann man keinen Krieg begründen." 38

But all the above stated seemingly rational goals of politics and political philosophy can serve as sources of legitimacy only provided that there is trust (faith) in rationality. The trust itself is something historically contingent. ${ }^{39} \mathrm{C}$. Schmitt expresses in that manner his doubt with regard to modern understanding of the power of reason as determinative agent in political development. ${ }^{40}$

The result of that modern shift consists in neutralization and depolitization that can be understood also in concepts of instrumentalization of human community, instrumentalization of modern state that can become tool of any arbitrarily directed individual demand. State per se is, according to Schmitt, certain historically conditioned form of political community. State is also carrier of sovereignty, able to provide for safety of its inhabitants in modern conditions. The problem and also the withdrawal of state from the positions acquired in modern age is given by transformation of state into mere tool of an individual. The individual is and is not the criterion of all things. The individual is not the criterion of all things to the extent to which human nature stops being determinative in its non-reducibility to which, according to Schmitt, the Catholic Church as 'complexio oppositorum' ensured anchoring outside the space of instrumentality. In this regard, C. Schmitt is also connected to

37 The following texts are important for understanding of the above stated Schmitt's position: The first is "Roman Catholicism and Political Form", the second, "The Concept of the Political". Compare SCHMITT, Roman Catholicism, 1996, 33-34: "The humanitarian philosophers of the eighteenth century preached enlightened despotism and the dictatorship of reason. They are selfassured aristocrats. Thus they based their authority and secret societies (i. e., strictly esoteric ass.) on the claim that they represent the idea of humanity." In "The Concept of the Political", C. Schmitt, in context of his delimitation of historical transformations of basic conceptual schemes, warns off the reductionism contained in modern substitution of God as source of legitimacy by something only seemingly universal: "Humanity as such cannot wage war because it has no enemy, at least not on this planet. The concept of humanity excludes the concept of the enemy, because the enemy does not cease to be a human being - and hence there is no specific differentiation in that concept. That wars are waged in the name of humanity is not a contradiction of this simple truth; quite the contrary, it has an especially intensive political meaning. When a state fights its political enemy in the name of humanity, it is not a war for the sake of humanity, but a war wherein a particular state seeks to usurp a universal concept against its military opponent. At the expense of its opponent, it tries to identify itself with humanity in the same way as one can misuse peace, justice, progress, and civilization in order to claim these as one's own and to deny the same to the enemy." See: SCHMITT, 2007, 54.

38 Carl SCHMITT, Positionen und Begriffe im Kampf mit Weimar - Genf - Versailles 1923-1939, Berlin 1988 , 71.

39 Carl SCHMITT, Legality and Legitimacy, London 2004, 15: "The legislative state seems to be something higher and ideal so long as the belief in the rationality and ideality of its normativism is still vibrant in times and in peoples that remain able to cultivate a (typical cartesian) belief in ideés générales."

40 Compare SCHMITT, 1988, 11: "In der Kraft zur Mythus liegt das Kriterium dafür, ob ein Volk oder eine andere soziale Gruppe eine historische Mission hat und sein historischer Moment gekommen ist. Aus der Tiefe echter Lebensinstinkte, nicht aus einem Räsonnement oder ein Zweckmässigkeitserwägung, entspringen der grosse Enthusiasmus, die grosse moralische Dezision und der grosse Mythus." 
the traditional political philosophy of virtue because that philosophy was well able to distinguish means and ends. On the contrary modern thinking, by losing contact with "good life" in its non-reducibility, absolutized the space of usefulness. But man also becomes criterion of all things if the individual as such, together with his demands and based on his arbitrariness, determinates even the use of state that, according to C. Schmitt, has become such tool. By instrumentalization of state, i.e. of a time-conditioned political form of human community, by instrumentalization of substantially human aspect expressed by Aristotle's definition of man in practical philosophy, man exposes himself to necessary danger of loss of orientation and thus to danger that he will miss his nature. ${ }^{41}$ During his examination in Nuremberg, C. Schmitt even suggested that he saw a result of the process of instrumentalization that finds its principles in individual immanency in Hitler's regime that was connected not only with his despotism but also with the completely uncontrollable desire of the Nazi elites to enrich themselves materially. The bond of the instrument to lower human capacities, as expressed in almost scholastic language, is shown in full force here, to Schmitt's considerable disgust. ${ }^{42}$

But that criticism covers only one part of thinking of modern age, the part following Hobbes and his concept of reason as calculation. Kant's political philosophy seemingly escapes Schmitt's criticism as he finds an autonomous criterion preventing reduction of human goals in the liberty constituting fundamental feature of rational beings. C. Schmitt copes indirectly with Kant's legacy. He responds by his conviction of impossibility of direct classification of concrete actions under an abstract norm; the criticism of formal normativism assuming the possibility of classification of particular actions under more general categories sounds in discussion with Hans Kelsen and leads Schmitt to conclude that each subsumption of that type is always based on decision, i.e. on will. ${ }^{43}$

41 See SCHMITT, 1970, 54: "Our contemporary society is progressive. This unfettered progress entails a value-free and scientific attitude, the commodification of all values and the augmentation of liberal human consumption. Futhermore, our society is made up of a plurality of social groups in which everything becomes plurivalent, and it is finally, as J. B. Metz says, a huminising [humanisierende] society. I think that such progressive, plurivalent, hominising society permits only that kind of eschatology which is immanent to the system and therefore only be a homo-homini-homo eschatology. At most this eschatology is an utopia on the principle of hope, the content of which is an homo absconditus who produces himself and moreover, produces the conditions for his own possibility."

42 In the text elaborated at R. Kempner's request during his one-and-half-year stay Nuremberg imprisonment, C. Schmitt returns deliberately to the topics from interwar period and specifically to "The Roman Catholicism and Political Form". In that text he compares the papal (Catholic) and totalitarian way of government and treatment of power by individual. The distinction of two ways of correction of power is important for our purposes. Schmitt writes in the text: "His [Hitlers] deliberate subjectiveness and therewith the fundamental abnormality of his regime is really unprecedented and incomparable. The head of the Roman Catholic Church, the Pope, is infallible according to the dogma of his Church, but his infallibility is nevertheless clearly limited to general determinations and its exercise is bound to the most distinct and transparent forms (ex cathedra). By comparison, Hitler decreed general and individual orders of all kind. He could decree laws, dissolve marriages, impose punishments or withdraw paternal authority as he wished, and could do so openly or secretly, verbally or in writing, with reason or as a passing fancy, so that fundamentally no one could control a "Führer Decree." See BENDERSKY, Interrogation, Appendix III, 1987, 122.

43 Hans Kelsen, native of Prague who shortly before publication of Schmitt's "Political Theology" published the book "The Problem of Sovereignty and the Theory of International Law", was leading European legal thinker and scientist. He is author of so called pure theory of law that strived to eliminate all subjective elements in law. In other words, H. Kelsen tried to formulate theory of law that would be universally valid in all situations. But according to C. Schmitt, all law is situational and non-reducibility of human life cannot be adequately captured by general formulations of law. Compare SCHMITT, 1985, 13: "All law is 'situational' law." 
So we can see manifestations of thinking of new age in refusal of tradition ('auctoritas'), in legal positivism and in normativism. C. Schmitt has serious doubts of justifiability of such shifts and offers political theology against mere political philosophy that strives to find legitimacy in rational or empirical substantiation. ${ }^{44}$ It does not give up authority of theology and, in this sense, breaks up with restriction of possibilities of substantiation of modern age. Thus political thinking depends to considerable degree on religious motives. "Silete theologi!" expressed by Alberico Gentili, mentioned in preface to "The Concept of the Political" from 1963, seems an unjustified requirement to him. ${ }^{45}$ "The Roman Catholicism and Political Form" expresses it by the following statement: "To every great politics belongs the arcanum." 'Arcanum', i.e. mystery that C. Schmitt cannot understand otherwise than as a way of understanding the concrete, escapes the range of calculation and formal rationality. That 'arcanum' requires affirmation to non-repeatability of our life and our decision. Theology derives its substantiation at least from two complementary sources. The first is the above stated failure of political philosophy that, particularly in thinking of modern age, overestimated reason and put aside the importance of trust in it. ${ }^{46}$ The second is the specific relation between theology and Catholic Church before the $2^{\text {nd }}$ Vatican council on one hand and man and the political on the other hand. We could understand the relation based on Schmitt's later work that lacks pro-Catholic enthusiasm of The Roman Catholicism and Political form, as relation between political theology, based on decision that takes place in dialogue, and political form corresponding to man. ${ }^{47}$ Theory is, alongside with philosophy, part of broader tradition of western political thinking that cannot be omitted in self-understanding of its own political situatedness, as the political is, both in traditional philosophy and in actual theology, an open problem requiring more than following a text or a norm. ${ }^{48}$

44 We can understand political theology in C. Schmitt's approach in two ways: a) as a project, characterized by $\mathrm{H}$. Meier in his "The Hidden Dialogue" as thinking that wants to answer the fundamental question of way of leading life in other manner and based on other sources than political philosophy does; b) as theory of secularization of originally theological concepts.

45 Compare Carl SCHMITT, Pojem politična, Brno - Praha 2007, 15.

46 "The Political Theology 2 " is subtitled: "The Myth of the Closure of any Political Theology". Myth takes an important place in Schmitt's thinking as an important agent determining political events. Unlike different political philosophies referring primarily to reason, it is able to motivate man to action. Thus although religion is not identical with myth, it shares the same influence on man with it.

47 But that statement has only time-limited validity. We can read the following in very important Schmitt's text "Roman Catholicism and Political Form", p. 8: "... Catholic Church is a complex of opposites, a 'complexio oppositorum'. There appears to be no antithesis it does not embrace." Ibidem, p. 8: "In contrast to the Protestant doctrine of the total depravity of natural man, this Creed speaks of human nature as only wounded, weakened, and troubled, thus permitting to some gradations and adaptations. The union of antitheses extends to the ultimate socio-psychological roots of human motives and perceptions." But according to C. Schmitt, the Catholic Church lost that unique feature after the $2^{\text {nd }}$ Vatican council. In this assessment of openness of the Church, C. Schmitt is very close to the significant criticist of the $2^{\text {nd }}$ Vatican council, Barion, to whom he dedicated the "Political Theology 2".

48 Compare SCHMITT, Roman Catholicism, 1996, 27: "But technical thinking is foreign to all social tradition: the machine has no tradition. ... A society built extensively on progressive technology would thus be nothing but revolutionary; but it would soon destroy itself and its technology." 
C. Schmitt considered Catholicism, at least in its early era, ${ }^{49}$ a kind of universal political form, 'complexio oppositorum' that, as such, corresponds to man's indefiniteness. His indefiniteness constitutes both the starting point of political theology and the difference from political philosophy. The latter is, according to C. Schmitt, always related to specific idea of man and to answer the question whether man is good or evil. Hobbes supported the second answer; Kant, on the contrary, was enlightened optimist overestimating the possibility of reason in determining will. Schmitt, by including the cardinal role of decision not only in his theory of sovereignty but also in his anthropology depending on relation to God that is confessionally antecedent, supported political theology. ${ }^{50}$

In his very special text, "Hamlet or Hecuba", he reflects on the difference between the figure of Hamlet and the figures of classical tragedies. They have in common the ability to act and not only to play. Action is based on decision, which is a necessary precondition for its tragicality. In this context we can, according to V. Kahn, read the above stated Schmitt's text as a specific form of apology 'pro vita sua'. ${ }^{11}$ But decisive for us is the fact that tragic action is given by decision according to Schmitt, deriving that motive directly from Kirkegaard. According to Kirkegaard, faith requires existential decision preceding any conceptualization of ethical or aesthetic character.

But Kirkegaard provides Schmitt with another clue that deepens his understanding of crisis of modern society and bounds directly the faith requiring decision with religion as a necessary social binder. According to Kirkegaard, modern life bears traces of arbitrariness; in Schmitt's words, Kirkegaard speaks of privatization in the sense that the individual acts rather based on his psychological predisposition. Schmitt agrees with Kirkegaard in this regard. Thus Schmitt's neutralization is nothing else than symptom of atomization of the society, the preconditions of which were given by loss of contact with tradition and therefore also with faith and speech. ${ }^{52}$

49 R. Wolin considers World War I a turning point in development of Schmitt's thinking and sees neuralgic point in decision that is antecedent to any culturally shared norms. But the question is whether such view is not too reducing with regard to Schmitt's understanding of theology. Theology is certainly not mere set of norms, directly accessible in the text of the Bible, but an attempt on understanding, dialogue, by which the western context of thought, determined by theology, differs for example of the Muslim context where theology stands only behind legal interpretation of holy texts. G. Schwab's interpretation, considering World War I as the point of C. Schmitt's breakup with neo-Kanthian belief of precedence of law over state, concurs with it. But that shift does not have immediate relation to our issue. For Schmitt's existentialism see Richard WOLIN, C. Schmitt, Political Existentialism, and the Total State, in: Theory and Society, 19, 1990, 4, 389-416; G. Schwab, Introduction to "Political Theology", p. xii.

50 See C. SCHMITT, 1970, 66: "Political theology is indeed a polimorphous phenomenon, and. Moreover, there are two different sides to it, a theological and a political one. Each is directed to its specific concepts. This is already given in the compositum of the phrase. There are many political theologies because there are, on the one hand, many different religions, and, on the other, many different kinds and methods of doing politics."

51 Victoria KAHN, Hamlet or Hecuba: Carl Schmitt's on Decision, in: Representation, 83, 2003, 1, 88-89: "I want to suggest that Schmitt's interpretation of Hamlet is a kind of apologia 'pro vita sua', one in which the most modern of early modern tragedies serves as an allegory for Schmitt's own "tragic" decisions. ... If Hamlet is tragic in the modern sense because he needs to decide about Gertrude's guilt, Hamlet is tragic in a classical sense because it dramatizes and objective religious conflict - and the objective necessity of a decision - with world historical implications. Just as Shakespeare's Hamlet transcends 'Trauerspiel' and become truly tragic, so ideally - does C. Schmitt."

52 Compare Søren KIERKEGAARD, Either/Or, Garden City 1959, 139: "Is not the invisible and spiritual bond lost which held the state together politically; is not the power of religion, which held fast to the invisible, weakened and annihilated?" 
Faith and theology constitute non-philosophical dimensions of Schmitt's political and anthropological thinking. Space for faith opens to the extent that is why later Schmitt's period is dominated by emphasis on decision. Faith can only be only individual, privatized matter, or the base of a broader community. Theology takes a special place in this relation. It constitutes connecting line between text, tradition and community in its historical situatedness. In this sense, theology constitutes the equivalent to speech on super-individual level. For that reason, C. Schmitt did not welcome the $2^{\text {nd }}$ Vatican council with its openness that would allow incursion of individualized public. ${ }^{53}$

\subsection{Political theology as process}

In "The Concept of the Political", Schmitt relativizes the basic conceptual framework in which we reflect on man and political structure of the society. He tells us three things: a) all spiritual concepts depend on political circumstances and concrete historical situation; ${ }^{54} \mathrm{~b}$ ) metaphysics of the given era has the same structure as the form of political organization; 55 c) the concepts with which political philosophy of modern age works are only secularized theological concepts.

Correct understanding of Schmitt's position can make use of very illuminating comparison performed by H. Meier in his book "The Hidden Dialogue", in which he follows the changes introduced by C. Schmitt in the 1933 edition of "The Concept of the Political", after having familiarized himself with L. Strauss' "Notes". In that edition, classified by Meier as surpassing those of 1922 and 1932, the whole passage sounds differently in a certain sense. C. Schmitt does not speak of spiritual concepts but of civilization concepts, i.e. according to period understanding, of concepts capturing the area of human actions and creation. It is a significant change as it helps us to understand the limits within which $\mathrm{C}$. Schmitt speaks of cognition. We could interpret cognition in the following way. The concepts in which man reflects on himself and on what he creates are not stable and change in the course of history. The second characteristic of cognition is its relation to political forms of the given society. There is dependence between concepts and vocabulary, which are historically vari-

53 The issue of Schmitt's anti-Semitism gets complicated just in this point. It is evident that he considered racially motivated anti-Semitism mere fantasizing. Nevertheless, in his comment to Leviathan, Schmitt criticizes very sharply Spinoza, accusing him that, following Hobbes, he provided tradition with tools the use of which led to privatization of religion and thus of speech. Two aspects of this problem are significant to our text: a) Is Schmitt's anti-Semitism given by this conviction of role of Jewish thinking in the process of depolitization and instrumentalization? Has thus Schmitt's anti-Semitism philosophical character? b) If, according to Schmitt, the relation of religion and speech is so close, then the Catholic Church that in the period before World War I corresponded to human nature is, due to its openness, also endangered by incursion of individuality, i.e. of the public.

54 SCHMITT, 2007, 85: "All concepts of the spiritual sphere, including the concept of spirit, are in themselves pluralistic and are to be understood only in terms of their concrete political existence." "All political concepts, ideas, and words have a polemical meaning; they have a concrete opposition in view, they are tied to concrete situation ..."

55 SCHMITT, 2007, 51: "The metaphysical idea of the world produced by a certain epoch is has the same structure as the form of its unquestioned political organization. The expression of this identical correlation is exactly the sociology of the concept of sovereignty. In fact it proves, as Edward Caird said on Auguste Comte, that metaphysics is the most intense and clearest expression of an epoch." 
able, on one hand and between the political forms of the given stretch of time. ${ }^{56}$

The character of our spiritual concepts or our concept framework we use when speaking about culture or civilization works at the same time as tool for diagnostics of modern political space. Both moments come together in the first sentence of "The Concept of the Political": "The concept of state presupposes the concept of the political". Thus state is understood by Schmitt as a specific realization in the political space. A realization conditioned both historically and "metaphysically".

C. Schmitt paid great attention particularly to the latter relation. The modern idea of state has its genealogy with beginning chiefly by T. Hobbes. That thinker of modern age and particularly his "Leviathan" was analyzed by C. Schmitt in a special text: "The Leviathan in the State Theory of Thomas Hobbes. Meaning and Failure of a Political Symbol" (1938) that constitutes not only philosophical interpretation of one of the best known texts of political philosophy of modern age but, at the same time, also determination of the causes of crisis of modernness and deep problems of liberal ideological framework. The text is also considered esoteric criticism of fascist totalitarianism, which is understandable, given that the emphasis on the sovereign's power disguises only externally the central point of Hobbes' political philosophy, i.e. the individual and the rule determining the limits of submission: "protego ergo obligo". What can we thus gain from Schmitt's interpretation?

"Roman Catholicism and Political Form" projected already Schmitt's belief that possessive and mechanistic relation to space, Nature, the Earth and man is not characteristic of "Catholic" understanding of life but modern and also Protestant understanding that separate Nature and spirit, Nature and culture too much. ${ }^{57}$ Such radical separation, according to Schmitt, is not characteristic of Catholicism that constitutes unity of contradiction ('complexio oppositorum'), thus corresponding to absolute indeterminableness and non-reducibility of human nature. The above stated base of "Roman Catholicism and Political Form" is thematized in narrow political aspect in the comment to "Leviathan". Hobbes defines the state not only as mortal god or great man but primarily as a mechanism, as creation of man that constitutes a tool serving to his survival. ${ }^{58}$ According to Schmitt, Hobbes' "Leviathan"

56 C. Schmitt takes a position in-between K. Marx and M. Weber. Marx sees the origin of changes in superstructure on the side of economic structure of the society, while Weber conditions changes of economic character by changes at ideological level. Schmitt's position is quite similar to that of M. Foucault. For more details to Schmitt's concept sociology see Michael HOELTZL - Graham WARD, Editors' Introduction, in: Carl SCHMITT, Political Theology 2, The Myth of the Closure of any Political Theology, Cambridge 1970, 5-8.

57 This point joins two Schmitt's theoretical approaches to transformations of our cognitive relation to reality, showing at the same time the connection between Protestantism and political-philosophical thinking of modern age: a) political theology is not only the project we discussed above but also denomination of Schmitt's belief that modern concepts describing political reality are only secularized theological concepts; b) modern age experiences change of the "paradigm" based on the above mentioned secularization of theological concepts. Hobbes' concept of the sovereign constitutes secularized concept of Calvin's God. See Carl SCHMITT, The Leviathan in the State Theory of Thomas Hobbes. Meaning and Failure of a Political Symbol, London 1996, 32. For more details on the connection between Protestantism and depolitization see Duncan KELLY, Carl Schmitt's Political Theory of Representation, in: Journal of the History of Ideas, 65, 2004, 1, 113-134.

58 SCHMITT, The Leviathan, 1966, 33-34: "The decisive element of the intellectual construction resides in the fact that this covenant does not accord with medieval conceptions of an existing commonweath forged by God and of a preexistent natural order. The state as order and commonweath is the product of human reason and human inventiveness and comes about by virtue of the covenant. This covenant is conceived in an entirely individualistic manner. All ties and groupings have been dissolved. Fear bring atomized individuals together. ... The state that came into being in the seventeenth century and prevailed on the continent of Europe is in fact a product of man and differs from all earlier kinds of political units. It may be even regarded as the first product of the age of technology, the first modern mechanism in a grand style, as a machina machinarum." 
only elaborates what was known already by Descartes' dualistic and mechanistic anthropology. But transformation of mechanicism to political level, to the area of reflections of 'polis', affects human nature much more deeply than it is with the case of Descartes. If man is primarily a political being, if making 'polis' (and state, in this case) a tool and a mechanism, then wide possibilities of its targeting will open and may not consist of the traditional good life. Schmitt shows the consequences of such release at the change of understanding of laws and legal system. If the cause of constitution of the state consists in calculation of individuals, if Hobbesian "non veritas, auctoritas facit legem" applies, then legal system becomes mere positive law that may therefore also serve as means leading to any goals. ${ }^{59}$ Thus modern constitutional state based on legal positivism has, according to Schmitt, its origin in T. Hobbes' theory. State is not God's architectonic creation as it still used to be in Descartes' approach, but a tool, the primary goal of which is delimited negatively - by restricting the extremely dangerous human nature that strives for nothing else but dominance. Hobbes, of course, formulates the advantages of safety of the state also positively - state is the condition of culture; but culture is also man's creation. L. Strauss, in his above stated Notes, pays attention to the fact that Schmitt's theory of the political, delimited by the possibility of determination of friend and enemy, has a much deeper level consisting in criticism of the concept of culture and civilization. At the beginning in Hobbes' approach by destroying the unity of human life in the sense that the spiritual space, unified until then and entirely aimed at 'good life' in secular area and at 'salvation' in spiritual area, is fragmented into many independent domains with own criteria. To medieval thinking, the idea of the universe was completed with the theory of transcendentals: 'unum', 'bonum', 'verum', 'ens', 'aliquid' and, according to U. Eco, also the transcendental: 'pulchrum'. The transcendental constituted the most general concepts to medieval philosophy and belonged to being as being; they were interchangeable. Nothing of that kind is possible to a man living after Hobbes; the good is not interchangeable with usefulness, beauty or truth. So Schmitt's friend/enemy pair to which he attributes more fundamental character constitutes criticism of pluralized idea of civilization and attempt to return to lost unity.

So when drawing on basic Schmitt's determination of the political as an area that is not comparable with and analogical to areas into which culture and civilization as man's creation has disintegrated, we get a homogeneous space in which, according to C. Schmitt, imaginary autonomy of aesthetics, business, law and moral ceases to exist; we get a space in which the seriousness of human life can be only disguised.

\section{Conclusion - how to consider man, God and war in C. Schmitt's approach?}

The seriousness of life is in the centre of Schmitt's criticism of modern concept of state, culture and civilization. The goal of political theology consists at least in making the seriousness of life at least a topic again, not only in the dominantly liberal space. In "The Concept of the Political", C. Schmitt tells us that he does not consider contradictory the

59 SCHMITT, The Leviathan, 1996, 68: "(...) law became a means of compulsory psychological motivation and calculable functioning that can serve different aims and contradictory contents." 
liberal ideal of non-political world society, i.e. a society not endangered by war, although it is in no case conceivable under current conditions. Schmitt even admits that such apolitical status, completely dominated by business (consumption), science and art could be very interesting and would certainly not lack amusement. According to Schmitt, the problem consists in whether interestingness and amusement as limits of the horizon of human life are not insufficient. His answer is hidden in the manner he sets up the whole problem in "The Concept of the Political". According to L. Strauss, the above stated "amusing character" of life in liberal ideal is completely inadequate to human nature. We could add that it is completely inadequate to its absolute openness and potentiality that, nevertheless, can realize its value only with regard to its responsibility for itself and towards God.

This criticism is based on the following reasons: a) although man is imperfect, his position is not desperate; the space of the political is open; b) man is an unrepeatable and historical being; decision is possible; c) his dignity consists in speech that anchors him in tradition and in the society. When posting the problem in this manner, it is completely legitimate to speculate about the differences originated in this manner, if comparing Schmitt's position with the above stated liberal ideal. The result may be startling to some degree.

The first point can be found completely within the tradition of Greek-Latin political thinking that does not order the political out of the limits of philosoper's and theologist's interest. Saint Augustine is not the right example in this aspect, but rather those thinkers of Christian tradition who followed Aristotle, drawing from his teachings in political philosophy. All Schmitt's interest in basic social determinateness of the individual and in his responsibility evidences the above outlined parallel.

The second point is based on Schmitt's emphasis put on the need of decision. If the liberal ideal of worldwide apolitical society is realized, and let's add on our behalf that such ideal is possible under full saturation of living needs; then all decision making would lose significance (gravity) as it would be situated only within the limits of economy, science and aesthetics. The above stated Saint Augustine enriched the ancient political-philosophical tradition with the importance of will for the value of our actions. Will as agent of true decision making makes the individual moral subject in the real sense of the word in his opinion, similarly to C. Schmitt's opinion. If man loses the need to make a decision, and the need is not where physical death does not delimit the horizon of decision making, man loses what constituted the centre of human dignity in the whole ancient-Christian tradition. It applies to Christian context at the same time that history has its beginning and end. Decision is unrepeatable. Medieval philosophy, represented for example by the figure of Thomas Aquinas, understood man's position in the universe in a completely specific manner. That tradition designated to man, unlike to intellects and animals, a place in which ethics and political philosophy are of importance in general sense. To animals, ethics and political philosophy are absolutely meaningless and irrelevant as they follow their instinct, i.e. also their effort to satisfy their needs. Perfect world of consumption is nothing else than a paradise of satisfied needs. To intellects, ethics and political philosophy are needless to the extent to which their purely immaterial existence does not make them mutually dependent and mutually dangerous. Here, we could see a parallel to the liberally-rationalist perception of man's initial position that, for example in H. Kelsen's approach, but in more modern age also in J. Rawls' approach, and in any case in Kant-inspired thinking, does not understand 
materiality and mutual existential dependence of man as primary point for determination of political space, unlike C. Schmitt understands it. Ethics and politics are significant only to man, due to mutual dependence and mutual possibility of threat. Both in case of the high-medieval thinking and in case of $\mathrm{C}$. Schmitt, thinker of the $20^{\text {th }}$ century, materiality plays central role in man's constitution, creating in both cases a horizon for decision that has sense and that cannot be taken back. To Schmitt, man is neither animal nor angel.

Extinction of the space in which serious decision has sense is related also to extinction of speech. To Schmitt, speech is not only a tool for exchange of information but, primarily, a bond. Catholic God is a personal God with whom direct dialogue can be carried on. As compared to him, man becomes mere creation, but the Creator remains his dialogue partner. This dialectic of simultaneous humiliation and elevation of man, specific to Christians, is enabled by dialogue in both vertical and horizontal direction. In the first case, it releases man from his indeterminateness; decision takes necessarily place in non-anonymous space. In the second case, the individual cannot be understood pre-socially, before the community of speech. ${ }^{60}$

So what role does war play in human life? C. Schmitt pays great attention to make clear what character belongs to each of the members of the friend/enemy opposites. It is always public friend or enemy. When he speaks of enemy, he considers it important to state his Latin equivalent - 'hostis' that means primarily a foreigner. A foreigner with whom speech is not possible. We do not wage a war with personal enemy ('inimicus'). Personal hostility leading to killing is never justifiable, neither morally nor religiously. Political hostility is manifestation and need of our physical determinateness and it exceeds the limits of morality:

"The often quoted "Love your enemies" (Matt. 5:44; Luke 6:27) reads diligite inimicos vestros, and not diligite hostes vestros. No mention is made of the political enemy. (...) The enemy in the political sense need not be hated personally, and in the private sphere only does it make sense to love one's enemy, i.e., one's adversary." ${ }^{61}$

Good and evil, are moral categories determining mutual relations of individuals with regard to their historical and cultural situatedness. On the contrary, friend and enemy are political categories determining the degree and the intensity of proximity or distance that, beyond a limit, may endanger the existence of the political grouping that the state is only in a particular historical period. The fact that Schmitt transfers war, that in Hobbes' approach constituted an admissible term for description of relation between individuals, exclusively to supra-individual level, reveals the seriousness of God's commandment not to kill, and at the same time sets place to the political in the space of choice. ${ }^{62}$ War, and that must be highlighted in C. Schmitt's case, is not the goal or a celebrated carrier of development. It

60 SCHMITT, Roman Catholicism, 1996, 24: "(...) it is a form of human dignity which become manifest in a rational form of speech." Ibidem, Appendix, 48: "Whoever speaks is no longer alone in the world. However, it would be false to say man is alone in the world and God is not with him. Instead of the alternative, that would be a combination of both. Man is either alone or in the world. As long as he is truly alone, he is not in the world, that is, he is no longer even a man, and as long as he is a man and in this world, he is not alone."

61 Ibidem, 29.

62 Ibidem, 48-49. 
is a horizon constituting a presupposition for serious decision.

"War is by no means the goal or purpose or even the content of politics. Being a real possibility, however, war is an ever existing presupposition which in peculiar way determines human action and thought thereby yielding a specifically political behavior."63

Schmitt's work is wide-ranging with regard to topics, time and contents. It interconnects the theory of law with political philosophy, theology and literature, under radically changing political events in which Schmitt was always engaged, although his actions crossing the borders of private sphere burden his legacy almost up to unacceptability. The elaboration of the topic aimed only at suggesting an interpretation of the relation of God and war that must necessarily be mediated by man. Based on the above stated statements, we can say that C. Schmitt does not work with any positive anthropology on the base of which political philosophy could be formulated with outlook to pacified and non-violent world. Man is, thanks to the possibility of his decision, fundamentally open to all possibilities. Finally even to the possibility directed only by his immanence. But authentic decision is a decision only if it is not mere affirmation of individual requests but if it takes place with full seriousness that is possible only in non-anonymous and non-private space.

\begin{abstract}
The text is focused on the analysis of the relation between God and war in political thinking interpreted by the controversial Carl Schmitt. It performs the analysis on the background of Schmitt's theory of the political and the political theology. In the first case, the theory of the political, based on the possibility of distinguishing the friend and the enemy, shows to be compatible with Christian political thinking and with Christian concept of man as a being capable of responsibility. This immanent context of Schmitt's political thinking leads to the need of establishing and analyzing the relation of God and war (violence). In the second regard, Schmitt's historical-epistemological model is presented on the background of political theology as project and program; the model relativizes the enlightened rationalist claim and rehabilitates, for the space of the political, also myth or faith as non-negligible political and epistemological factor that, at the same time, prevents instrumentalization of polis. A complement to political theology as historical-political process consists in political theology as a project taking into account theology, belief in God, together with systematic considering of facticity of violence. Thus the relation of God and war can be analyzed at two levels; both of them are discussed in the article. First, at the level of its withdrawal from political thinking and of the consequences resulting from it. And second, from the perspective of its function in political thinking that would correspond to human character as 'complexio oppositorum'.
\end{abstract}

63 Ibidem, 34-35. 


\section{Keywords}

God, violence, war, friend, enemy, political theology, depoliticization, instrumentalization, theology, ideology

\section{References}

ARENDT, Hannah: On Revolution, Harmondsworth 1963.

BALAKRISHNAN, Gopal: The Enemy: An Intellectual Portrait of Carl Schmitt, London 2000. BENDERSKY, Joseph W.: Carl Schmitt: Theorist for the Reich, Princeton 1983.

BENDERSKY, Joseph W.: Carl Schmitt at Nuremberg, in: Telos, 20, 1987, 72, 91-96.

BENDERSKY, Joseph W.: Interrogation of Carl Schmitt by Robert Kempner. in: Telos, 20, 1987, 72, 97-129.

BOBBIO, Norberto: Thomas Hobbes and the Natural Law Tradition, Chicago 1993.

DROBNER, Hubertus R.: Patrologie: Úvod do studia starokřestanské literatury, Praha 2011.

DYZENHAUS, David: Legal Theory in the Collapse of Weimar: Contemporary Lesson?, in: American Political Science Review, 91, 1997, 1, 121-134.

HERBERT, Ulrich: Geschichte Deutschlands im 20. Jahrhundert, München 2014.

HOELTZL, Michael - WARD, Graham: Editors' Introduction, in: Carl SCHMITT, Political Theology 2, The Myth of the Closure of any Political Theology, Cambridge 1970, 5-8.

HOLLERICH, Michael: Carl Schmitt, in: Peter SCOTT - William T. CAVANAUGH (Eds.), The Blackwell Companion to Political Theology, Oxford 2004.

JACOBSON, Arthur. J. - SCHLINK, Bernhard: Weimar. A Jurisprudence in Crisis, Berkeley 2000.

KAHN, Victoria: Hamlet or Hecuba: Carl Schmitt's on Decision, in: Representation, 83, 2009, 1, 67-96.

KALYVAS, Andreas: From Act to the Decision: Hannah Arendt and the Question of Decisionism, in: Political Theory, 32, 2004, 3, 320-346.

KELLY, Duncan: Carl Schmitt's Political Theory of Representation, in: Journal of the History of Ideas, 65, 2004, 1, 113-134.

KIERKEGAARD, Søren: Either/Or, Garden City 1959.

LAAK van, Dirk: Gespräche in der Sicherheit des Schweigens. Carl Schmitt in der politischen Geistesgeschichte der frühen Bundesrepublik. 2. Auf., Berlin 2002.

MEIER, Heinrich: The Lesson of Carl Schmitt: Four Chapters on the Distinction between Political Theology and Political Philosophy, Chicago 1998.

MEIER, Heinrich: Carl Schmitt and Leo Strauss. The Hidden Dialogue, Chicago and London 2005.

MlŁOSZ, Czesław: The Captive Mind, New York 1955.

MOUFFE, Chantal: The Return of the Political, New York 1993.

QUARITSCH, Helmut: Positionen und Begriffe Carl Schmitts, Berlin 2010.

SCHMITT, Carl: Theodor Däublers "Nordlicht" - Drei Studien über die Elemente, den Geist und die Aktualität des Werkes, München 1916.

SCHMITT, Carl: Der Führer schützt das Recht. Zur Rechtstagsrede Adolf Hitlers vom 13. Juli 1934, in: Deutschen Juristen-Zeitung, 15, 1934, 39, 945-950. 
SCHMITT, Carl: Political Theology 2. The Myth of the Closure of any Political Theology, Cambridge 1970.

SCHMITT, Carl: Theorie des Partisanen. Zwischenbemerkung zum Begriff des Politischen, Berlin 1975.

SCHMITT, Carl: Political Theology. Four Chapters on the Concept of Sovereignty, Cambridge 1985.

SCHMITT, Carl: Political Romanticism, Cambridge 1986.

SCHMITT, Carl: Positionen und Begriffe im Kampf mit Weimar - Genf - Versailles 19231939, Berlin 1988.

SCHMITT, Carl: Über die drei Arten des Rechtswissenschaftlichen Denkens, Berlin 1993.

SCHMITT, Carl: Roman Catholicism and Political Form, London 1996.

SCHMITT, Carl: The Leviathan in the State Theory of Thomas Hobbes. Meaning and Failure of a Political Symbol, London 1996.

SCHMITT, Carl: Ex Captivitate Salus, Berlin 2002.

SCHMITT, Carl: Legality and Legitimacy, London 2004.

SCHMITT, Carl: Pojem politična, Brno - Praha 2007.

SCHMITT, Carl: The Concept of the Political, London 2007.

SKINNER, Quentin: The Foundation of Modern Political Thought: Age of Reformation, Cambridge 2004.

SLOMP, Gabriella: Carl Schmitt and the Politics of Hostility, Violence and Terror, New York 2009.

STRAUSS, Leo: Notes on Carl Schmitt "The Concept of the Political", in: Heinrich MEIER, Carl Schmidt and Leo Strauss. The Hidden Dialogue, Chicago 1995, 97.

VOEGELIN, Eric: The New Science of Politics: An Introduction, Chicago 1974.

WOLIN, Richard: C. Schmitt, Political Existentialism, and the Total State, in: Theory and Society, 19, 1990, 4, 389-416. 